\title{
THE WARTA RIVER VALLEY IN THE DĘBINA AREA OF POZNAŃ - CHANGES IN LAND COVER AND LAND USE IN THE CONTEXT OF NATURAL ASSETS AND LANDSCAPE QUALITIES
}

\author{
Bożena Łukasik ${ }^{凶}$, Agnieszka Wilkaniec, Agnieszka Targońska \\ Department of Landscape Architecture, Poznań University of Life Sciences, ul. Dąbrowskiego 159, 60-594 Poznań
}

\begin{abstract}
Aim of the study

Located to the south of the centre of Poznan city, Dębina is a valuable natural and landscape area, used for recreational purposes. This work's objective is to identify natural values (assets) and landscape qualities and to establish the reasons for their transformation in the Dębina area, as well as determining the level of changes in land use and land cover, in order to capture the relationship between natural-landscape conditions and human activity.
\end{abstract}

\begin{abstract}
Material and methods
In the course of the work, functional analysis and identification of contemporary threats for Dębina will be performed, based on the analysis of historical materials and contemporary cartographic materials using GIS tools.
\end{abstract}

\begin{abstract}
Results and conclusions
Significant transformation of the environment in this area started with the construction of the water intake at the beginning of the twentieth century. Other investments related to the development of the city and the region also had a significant impact. The transformations that were unfavourable for natural environment and the landscape became the reason for taking corrective action, aimed at preserving and protecting natural components. Today, Dębina is an example of coexistence and interconnectedness between natural and cultural elements. As an area located in the Warta river valley, it is a part of an ecological corridor of national importance, and at the same time, it forms a part of the ECONET PL European ecological network. The results of the research - namely, determining the scale of the changes to land cover and land use in subsequent time periods - may become the basis for formulating guidelines for future management of this area, and for the protecting its natural values.
\end{abstract}

Keywords: urbanization of river valley, degradation of ecosystems, ecological network, landscape risks

\section{INTRODUCTION}

Dębina is an area located on the left bank of the Warta river, south of the centre of Poznań. Due to its outstanding natural and landscape values, for a long time, this area has provided favourable conditions for recre- ation of the city's residents. The main attraction was the largest cluster of fine oaks throughout the Poznan area (Szafran, 1959). The river valley has been incorporated into the "green wedge" system of the city. Being a flood plain, the area remained undeveloped for a long time. Various plant communities developed

凹e-mail: bozena.lukasik@mail.up.poznan.pl 
here, characteristic for this type of habitat. Studies conducted in this area over 100 years ago indicated the richness of plant and animal taxa (Ritschl, 1850; Kiehl, 1908; Hanisch, 1909).

The article deals with the changes taking place under the influence of urbanization in the naturally shaped river valley. Land uses and land cover in the area are subject to transformations, as well as mutual spatial relations of anthropogenic and natural elements. Comparison between the old (historical) and the contemporary landscape structure allowed us to determine the direction and pace of transformations.

The objective of the present work was to identify natural and landscape transformations in the area of Dębina in subsequent historical cross-sections, and to establish their causes, as well as to determine the relationship between natural landscape conditions and human activity in the said area. A functional analysis was also conducted, and contemporary threats to the natural values and landscape qualities of Dębina were identified.

The subject matter of this work is focused on the transformation of nature and landscape related to human activity. International and Polish researchers alike are currently addressing a number of issues in this field. Among research carried out by Polish scientists, it is worth paying attention to a comprehensive, systematic approach to landscape issues. Macias and Bródka (2014) present components of the natural environment, such as: geological structure, forms of the terrain, soil, underground and surface water, atmospheric air and climate, as well as biotic components. They indicate the criteria for assessing the qualities of the environment as well as suitability and feasibility of various ways for the management and development thereof. In turn, Szponar (2003) notes that within the natural environment there exist very complex interconnections, which are additionally complicated by the changes resulting from anthropogenic pressures. Many human activities lead to transformations, including the degradation of urbanized areas. Richling and Solon (2011) emphasize that the individual components of the landscape, interrelated and interacting with one another, form a variety of spatial structures (i.e. chorostructures). These structures are subject to transformation, or evolution, consisting in the increase of systems' complexity. There are currently only few primeval, natural landscapes. The authors point out that the term "cultural landscape" seems to be inaccurate today, as most contemporary landscapes bear the hallmarks of human activity, while simultaneously retaining some natural elements. Chmielewski (2012) devotes a lot of attention to the problem of planning landscape systems. He believes that harmonious landscapes are of essential significance for the quality of life of the community. Landscape systems are often created on the basis of naturally valuable areas, which may be specific nodes of larger structures. Individual node areas, connected by a system of ecological corridors, form an ecological network, which is conducive to preserving the natural balance (Szulczewska 2004). Chmielewski (2001) indicates, however, that the protection of natural values within a city can play the role of a control mechanism, which checks and steers the development of individual areas (for instance, by limiting the expansion of construction sites). An important factor influencing the state of natural assets is urbanization. The latter is considered the second most important factor - second only to agricultural production - threatening natural ecosystems, with the most durable and the most degrading effect (Treby and Castley, 2016). Urbanization can cause degradation of valuable ecosystems and contribute to the destruction of mutual links between them. In particular, the development of communication infrastructure contributes to the fragmentation of valuable natural areas and of the landscape (Fu et al. 2010, Bruschi et al. 2015). Growing size of built-up areas and road infrastructure contributes to reducing the share of forests and other open areas (Bradshaw, 2012), thus increasing pollution of the natural environment, including waters (Maheshwari and Bristow, 2016), air and soil (Zhang, 2016), limiting biodiversity, and posing a threat to a large number of plant and animal species (Hamer and McDonnell, 2008; Border et al., 2017).

\section{STUDY AREA, SCOPE, AND METHODOLOGY}

The research covered the area located along the Warta river, limited from the north by Królowej Jadwigi street and the bridge, and from the south, reaching the border of the city. Dolna Wilda street (running along the once natural slope of the Warta river valley) was adopted as the western boundary for this study. The 
eastern border was marked by the course of the river. A part of this area consists of ecological sites of Dębina I and Dębina II (see: Fig. 1).

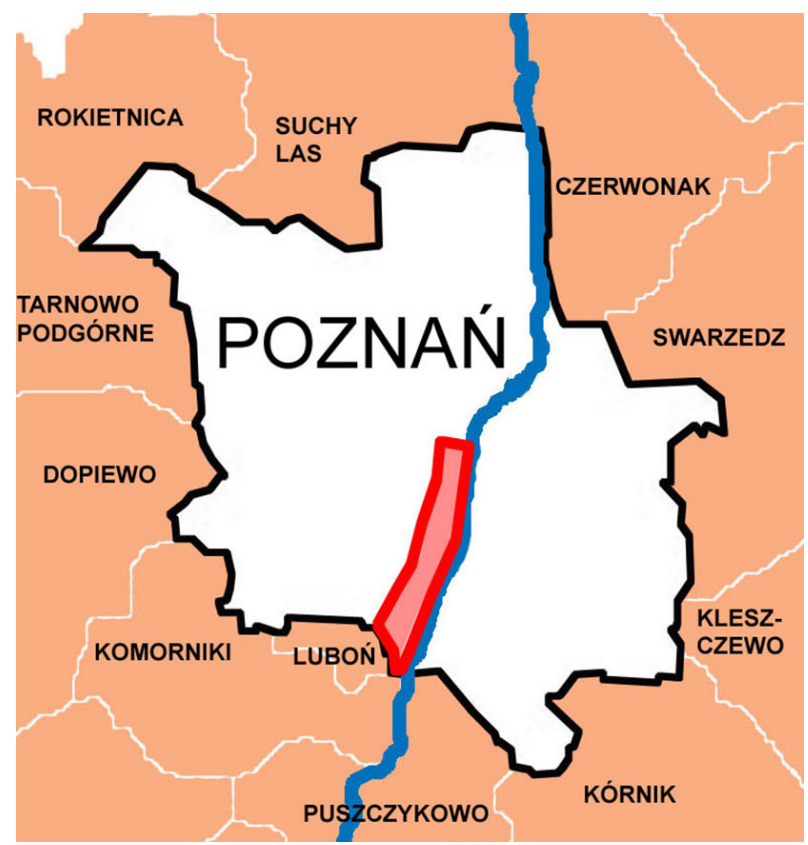

Fig. 1. Location of the research area (Source: compiled by B. Łukasik)

In the course of the research, queries of source materials and subject literature concerning Dębina were conducted. This area has long attracted the interest of researchers representing various fields of science. The most important natural studies of the early twentieth century include the German publication by Schumann (1904) describing the beetles encountered here, or the article by Kiehl (1908), presenting the advantages of Dębina as a rest area for the residents of the city. The last and most comprehensive study on the nature of the studied area is Badania florystyczno-faunistyczne oraz ocena naukowa walorów przyrodniczych użytku ekologicznego „Dębina” (Study of flora and fauna and scientific assessment of the natural assets of the 'Dębina' ecological site) by Wrońska-Pilarek et al. (2001). In the later period, research carried out in this area concerned selective issues such as dragonflies (Zawada, 2015).

On the basis of the subject literature and available documentation, the basic causes and directions of transformations that occurred in this area from 1830 to 2015 were identified, and the natural assets and landscape qualities were determined. In the further part of the work, the dynamics of spatial changes in the land cover and land use within the Depbina area was analysed. Periods for collecting data based on cartographic materials were: the 1830s (Urmesstichblatt, 1830), the beginning of the 20th century (Messtichblatt, 1919), the end of the 20th century (Mapa topograficzna/Topographic map... 1998), and the present period (Ortofotomapa/Orthophotomap, 2015). This selection of historical sections served the presentation of the spatial status of the analysed area in the past, and the identification of the changes in land cover and land use. Surface measurements were made using the ArcGIS 10.1 software. The basis for the analysis of contemporary land use and land cover was the BDOT 10k database and aerial photographs available online in the ArcGIS libraries (Ortofotomapa/Orthophotomap, 2015). Historical cartographic materials have been added to the map content and subjected to georeferencing. Then, individual surfaces were measured in subsequent historical sections. Surface changes of particular types of land cover and land use in subsequent temporal sections were calculated. For subsequent temporal sections, the data from the previous period were taken as baseline.

The measurement results are presented in Table 1. On the basis of the above analyses, percentage share of the surface were determined for the discussed types of land cover and land use for subsequent periods.

\section{RESULTS}

\section{Reasons and directions of Dębina area transforma- tions}

Since the 15th century, Dębina has belonged to the Calced Carmelite monastic church of Corpus Christi (Nowacki 1964). In 1621, the townspeople from Poznań conducted depleting logging in the riparian forest, inflicting serious damage to the forest stand. Losses were estimated at about 3 thousand young oaks, and an infinite number of other trees. Dębina suffered another loss in 1703 (Szafran, 1959) during the Swedish invasion (300 oaks were cut down at that time) and in 1720, when a significant number of oaks were felled to make way for establishing the village of Dąbczyn 
(Karolczak, 2004). In 1795, the Carmelite Order was dissolved, and the Dębina area was taken over by the Prussian government. During the Grand Duchy of Posen, the wife of the Governor of the Duchy, Antoni Radziwiłł - Ludwika (Princess Louise of Prussia) had her hunting palace there. For the convenience of Princess Louise's journey in 1816, a road connecting the property with the city was built (Karolczak, 2004). The Princess made the area of the Dębiński forest available as a rest area for the residents of Poznań, which, however, did not favour the area's conservation. In the years 1826-1827, there were numerous cases of destruction of greenery, especially of young trees, and it was necessary to introduce regulations for those who visited or stayed in the area (Karolczak, 2004). In 1895, the wooded area of Dębina with an area of 172 ha was taken over by the administration of the city (Pogorzelski, 1973). The remaining area of Dębiec was incorporated into the Poznań city as late as 1925 (Regulation of the Council of Ministers of the Republic of Poland, December 17, 1924).

The area of Dębiec (today, a district of the city) has been permanently transformed after it was divided by railway tracks. In 1856, a route from Poznań towards Wrocław was built. Then a railway line to Kluczbork was established. In 1874, the construction of the railway embankment crossing the forest area in Dębina was completed, and in 1875 the Starołęcki bridge was put into use. In the 1940s, tracks were built from Luboń to Starołęka (Paradowska, 2004; Karolczak, 2004). Moreover, at the end of the 19th century, the river was regulated, thus straightening its course south of Poznan, and depriving it of active branches and bends (Kaniecki, 2004). In this way, the so-called Dębina ponds were created.

In 1900, a project was put in place to transform Dębina into a folk park, the authors of which were garden inspector Hermann Kube and municipal building councillor Fritz Teubner (Karolczak, 1993). The plan showed smoothly routed alleys with a clearly marked ring road, areas with groups and massifs of trees, and open clearings between them (see: Fig. 2). The form and manner of spatial development of this area referred to the solutions of the nineteenth-century landscape parks. In the area of the park that was being developed, the question of water relations required regulation most particularly - as it was necessary to fill the landlocked swamps, as well as to form picturesque ponds connected to form a system maintaining an even water level. These works were interrupted by the outbreak of the First World War (Karolczak, 1993). After the war, they continued, although the importance of Dębina as a recreational area for the city's residents gradually decreased.

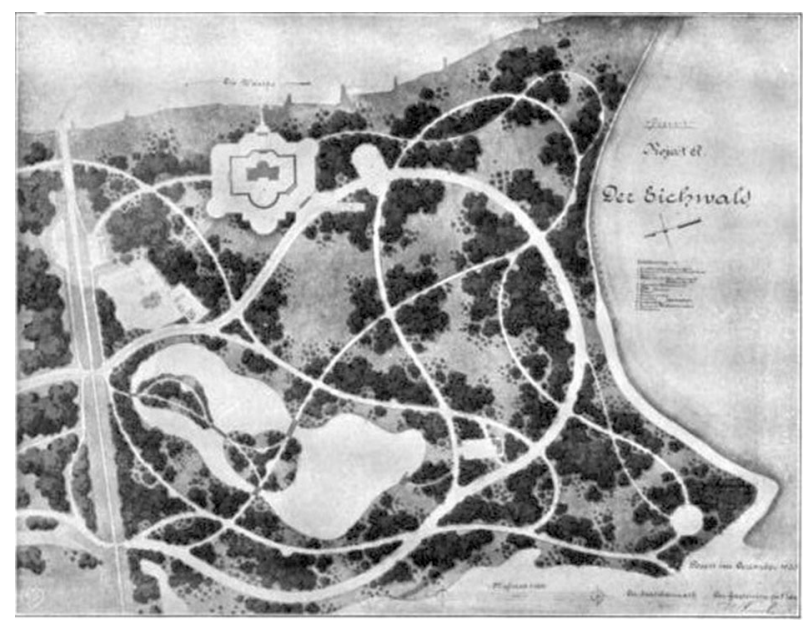

Fig. 2. The plan of Dębina forest park - 1900 (Source: Hoffmann, 1900)

1902 was a breakthrough year. At that time, the decision was made to dig several dozen wells of the municipal water intake in the southern part of Dębina. Their location was not accidental, as previous studies showed favourable hydrogeological conditions. The water intake was extended towards the south, and work continued until 1964 (Przybyłek, 2004). Construction of infiltration ponds in the 1920s adversely affected the natural environment. The transformation consisted mainly in lowering the level of groundwater, which resulted in a mass dieback of trees (Wodziczko, 1930a) and the change in the species composition in the Warta ecosystem, which continues to this day. During the Second World War, the route of the motorway, designated by the Germans, was located within the area of the Dębina intake. This concept was again taken up in the 1990s - this time by Polish designers who then had to face an additional difficulty, namely the extended water intake zone (Madaj, 2004).

In the 18th century, the area located north of the forest was occupied by the so-called Łęgi Dębińskie - 
city meadows, formed after logging the riparian forest. A broad trail ran through it, highlighted by a magnificent four-row poplar alley, connecting Dębina with the city. Areas on both sides of the road remained undeveloped - because they were marshy meadows. Due to the frequent flooding of the road, it became necessary to remodel it so that it would remain above the flood level. During the works, avenue trees were removed along with and a large stretch of Dębina's Warta river forest with old trees (Zaremba, 1946). In the nineteenth century, there were numerous garden restaurants along the Dębina road (the latter existing until today), which attracted crowds of Poznań's residents, eager for entertainment (Wodziczko, 1936). The area was rich in many facilities, including a river bathing resort (1924); the "Dzieciniec pod Słońcem" - Kindergarten under the Sun, the first "Jordan Park" (youth garden) in Poznań (1927-1928); and Park Kultury i Wypoczynku (Park of Culture and Leisure), today John Paul II's Park (1970). Before the Universal National Exhibition in 1929, a municipal stadium was built here and allotment gardens were established (Kodym-Kozaczko, 2014).

Dębina lost its importance as a recreational area after the Second World War. Since the 1980s, efforts have been undertaken to organize the forest area, to renew and regulate water reservoirs, and to equip Dębina with recreation facilities (Karolczak, 2004).

\section{Natural assets and their protection}

Warta river, which borders the studied area, is the axis of the natural system of Wielkopolska region. The river forms an ecological corridor of national importance, and is an element of the EURONET PL European ecological network (Liszkowska et al. 2009). The concept of the "green wedge" - the green corridor system of Poznań, developed in 1932 by Władysław Czarnecki, took into account the existing greenery complexes (Kodym-Kozaczko and Kozaczko, 2014). The area of Łęgi Dębińskie and Dębina forests was located within the southern green wedge, located along the Warta river, and constituted the largest compact complex of existing greenery within Czarnecki's plan (see: Fig. 3).

The river valley is a zone of natural overflow area and related natural habitats. Human land management within it disrupts the existing balance and distorts the course of many natural processes. The studied area is subject to diverse anthropogenic pressures. As a flood plain, it remained undeveloped for a long time, but eventually, as the city developed, its various fragments gained various functions (see: Fig. 4). These areas differ significantly in terms of their natural assets and landscape qualities.

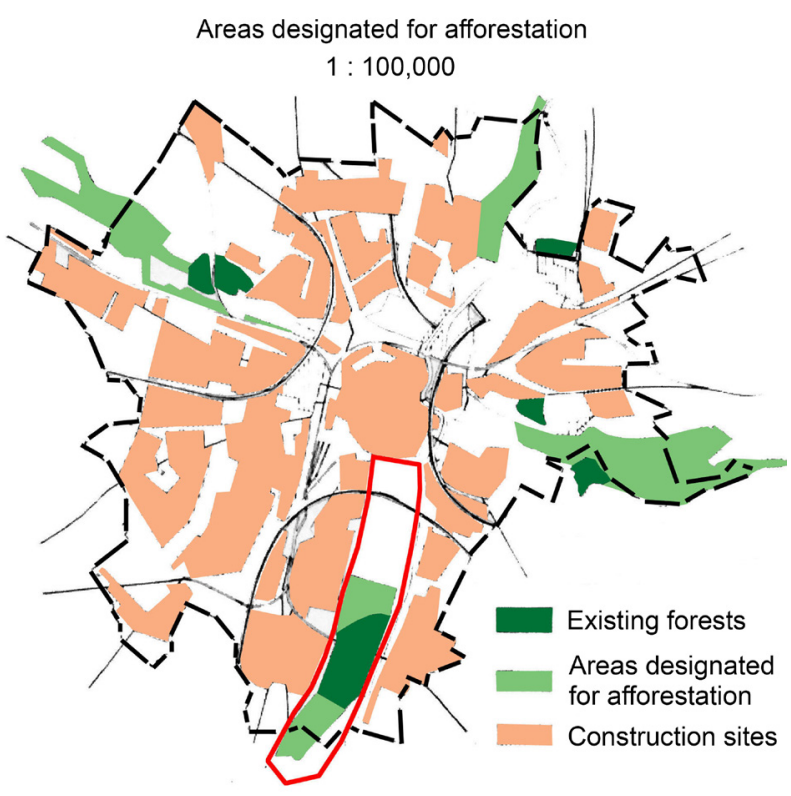

Fig. 3. Professor Adam Wodziczko's plan showing the forest in Dębina and the neighbouring areas designated for afforestation. The area discussed in this study is marked in red. (Source: compiled by B. Łukasik based on A. Wodziczko's plan)

Certainly it is the woodland area of Dębina that remains of the highest value. It is overgrown by old trees, and has long been studied by naturalists. Research has shown the presence of numerous taxa of fungi, plants and animals, including many protected species. On May 10, 1994, the "Dębina" ecological site was established. The protected area covered 110 ha (or 133 ha, according to Annex 1 part 8 Uchwała No. CV/610/94 (Urbańska et al., 2015). The ecological site status has been removed with the entry into force of the amendment to the Nature Conservation Act of December 7, 2000 (Journal of Laws of 2001 No. 3, item 21). The basis for the re-appraisal of the Dębina 


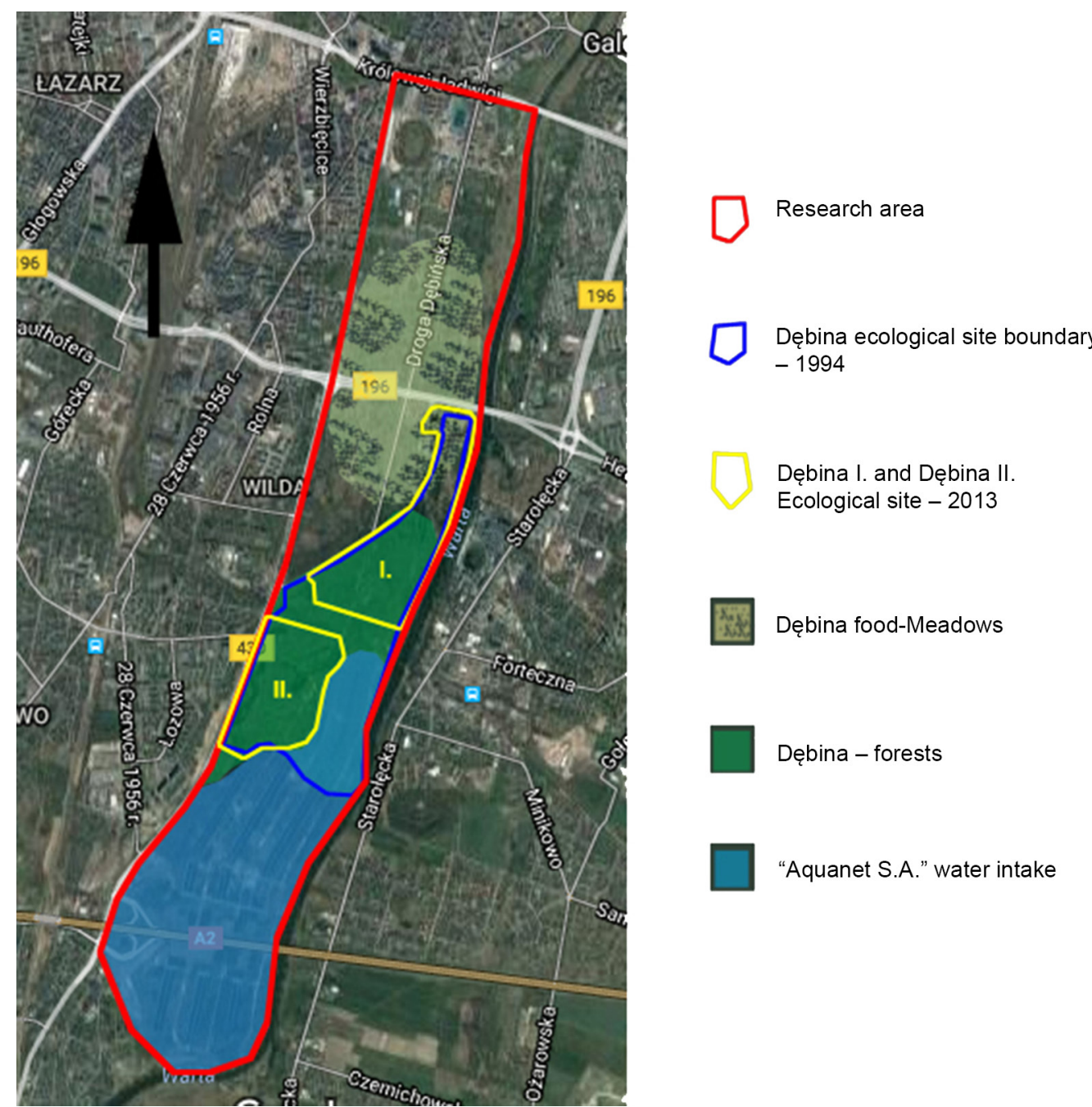

Fig. 4. A functional and spatial scheme of Dębina (Source: compiled by B. Lukasik)

area as a protected area consisted in the resolutions by the Poznań City Council of December 10, 2013, No. LX/924/VI/2013 and LX/925/VI/2013, which established two ecological sites called "Dębina I" (53,57 ha) and "Dẹina II" (31.06 ha) separated by the embankment with railway tracks. As it appears from the content of the resolutions, both sites were created "in order to protect fragments of an old oak tree stand, constituting a remnant of the former riparian forests of Dęblin, growing in the Warta river valley, along with the remaining old trees and ponds". Compared to the ecological site of "Dębina" established in 1994, the protected area was reduced by 25.37 ha.
Ecological sites Dębina I and Dębina II constitute areas of considerable floristic value. The most valuable plant complexes occupy aquatic sites (rushes with reed manna grass, moist meadows and riparian forests around ponds, a belt of undergrowth and riverside meadows along the Warta river). Among the vascular plants, 498 taxa were recorded (Wrońska-Pilarek, 2001). Of these, 128 species have been recognized as disappearing and threatened with extinction in the city of Poznan, 8 are subject to legal protection, and further 5 are classified as endangered plants in Wielkopolska region. Within both ecological sites, in 2015, 371 plant species from 72 botanical 
families were found. Compared to the results of research conducted since the 1840 s, we have lost many valuable species associated with wetlands. The impoverishment of the local flora is the result of rapid changes in water relations caused by the creation of a drinking water intake for Poznan city in the area. Despite this, it is considered that among other forest areas in Poznań, the Dębina remains the closest to the natural forest state, and the local riparian forests are among the best preserved (Dyderski and Wrońska-Pilarek, 2015).

Dendroflora comprises 106 taxa, predominantly deciduous species. The species composition is diverse, with significant anthropogenic impact (Wrońska-Pilarek and Stasik, 2001). $44.8 \%$ of the species found here are of foreign origin, while some occur outside the limits of their natural ranges. Species occurring herein are associated with the communities of fertile deciduous forests (riparian forests, oak-hornbeam and alder); there are also plants characteristic for shrubby, fresh and moderately moist and moist meadows as well as riverbank forests, rushes and water communities (Wrońska-Pilarek and Stasik, 2001). Among the identified tree species, 4 are covered by legal protection, 6 are on the red list of endangered and disappearing species in the Wielkopolska region, and 18 are on the list of "special care species" for the city of Poznań. Many trees have reached substantial sizes - in 1956, 86 specimens were considered "nature's monuments" (Resolution, 1956). 40 years later, 88 trees with nature's monument dimensions, 67 trees with dimensions close to that of nature's monuments $( \pm 10 \%)$ and 160 stately trees (Wrońska-Pilarek and Stasik, 2001) were found in the area of ecological site that existed here until 2000. In 2001, the oldest trees were: an English oak (estimated at 140-190 years), a Scots pine (140-180 years old), a European white elm (115-145 years old), a small-leaved lime (115-145 years old), a common beech (145 years), a common ash (120-140), a European hornbeam (100-130), a poplar (90-130), a maple (120), a black alder (90-120 ), and a red oak (115). Specimens of other species did not exceed the age of 100 years.

After the Second World War, 73 species of lichens were identified (Kepel, 2001). Unfortunately, 34 of them were no longer to be found by the beginning of the 21 st century. For two species, this is their only lo- cation within Poznan. Six species in the Dębina area are subject to strict legal protection, and eight are on the "red list" of endangered lichens in Poland. In recent decades, there has been a significant loss of protected and endangered species, which is associated with an increase of air pollution in Poznań. In the mosses group, 26 species were recorded (Wrońska-Pilarek et al., 2001). Three of these are covered by partial protection, and one is very rare within the Wielkopolska region.

The kingdom of fungi is represented, among others, by a giant puffball (Langermannia gigantea) - the largest mushroom in Poland, and a new parasitic straw mushroom (Volvariella surrecta), with the only known location throughout Poland (Celka, 2002).

The Dębina area abounds in various species of animals. 142 species of vertebrates subject to legal protection and another 42 species covered by hunting and fishing protection were found in the discussed area. Birds (85\%) have the largest share among these animals, which at the same time constitute $56 \%$ of Poznań's avifauna (Wrońska-Pilarek et al., 2001). Their wealth was described already in the pre-war period. The maximum number of bird species recorded in this area (including the water intake area) was 122, some of them classified as rare (Wrońska-Pilarek et al., 2001). Four protected species have been identified among invertebrates. In 1959, it was observed that due to the elimination of aquatic undergrowth, the nesting places of some bird species (such as kingfisher) had disappeared. The number of fish, clams and snails also decreased significantly (Szafran, 1959). At the beginning of the 19th century, data on numerous beetles were reported (Schumann, 1904). Contemporary studies have shown the presence of only two species of common carabids (Wrońska-Pilarek et al., 2001).

The area of drinking water intake is of lesser natural importance. Studies carried out in 2009 have shown that the flora here shows the marks of human intervention, and its value on the adopted scale can be described as moderate to insignificant. The most valuable areas are located in the vicinity of the Warta river, in the northern and western part of the area. Furthermore, a large proportion of forest areas (mainly of anthropogenic origin), water reservoirs (mainly artificial) and open areas with grassy vegetation were found 
(Liszkowska et al., 2009). In the area of the water intake, mainly in the northern part, there are 32 trees recognized as natural monuments (English oaks, English elms, Canadian poplars, black walnuts, maples, and common pines). The age of the stand is varied. The oldest trees (about 150 years old) grow in the northern part; the central part is dominated by $60-80$-year-old stands, whereas in the southern part the age of trees is estimated at about 60 years (Górski, 2013). The rich animal world is noteworthy, with numerous species inhabiting forests, grassland and water reservoirs. The very limited and sporadic human interference is to their advantage (Liszkowska et al., 2009).

The modernization works (well drilling and drainage) carried out by the municipal water and sewage company Aquanet SA potentially pose a threat to the reduction of groundwater resources and deterioration of their quality. On the other hand, the fact that a valuable tree stand is neighbouring the water intake, in a manner of speaking, provides a guarantee of the former's protection, because the area of the Dębiński forest and other nearby areas constitute an area of indirect protection (a buffer zone) for the water intake in Dębina (Protective zone map, 2015).

As a result of the construction of the A2 motorway and the creation of a buffer zone protecting it against unfavourable impact of the construction project, it was possible to exclude a large area of Dębina from the existing land use scheme. The motorway is a potential hazard - because it can contaminate water (as there is no system for discharging rainwater from the road surface beyond the water intake area) or cause leakage of hazardous substances to water as a result of vehicle collisions. In addition, air pollution is transferred from the motorway.

The remaining areas in the Dębina region have been strongly transformed and urbanized, and as a result their natural value has decreased.

\section{Landscape qualities}

The forest area of Dębina was described more than 100 years ago as exceptionally picturesque (Kiehl, 1908, Hanisch, 1909). Abundant trees were surrounded by the expanses of water bodies, on nearly every side. The water bodies consisted of forked legs of the Warta river and small streams connected therewith. Also inside the forest area there were vast reservoirs, more or less rich in water, depending on the current water level of the river. The thick, shadow-providing tree stand contrasted with water surfaces and extensive sunny glades. In the forest formed mainly of English oaks, groups of trees such as birch, pine, and spruce stood out. People enjoyed a relaxing time along the banks of the river, while watching steamers and boats passing by. The area north of the railway line was perceived as the most charming (Kiehl, 1908).

In 1930, the Warta river near Poznań was recognized by Professor Wodziczko (1930b) as a substantial asset, decisive for the beauty of the Wielkopolska landscape, due to its varied if vestigial vegetation. Later researchers (Wrońska-Pilarek et al., 2001) noted that the main causes of the changes in the discussed area included: regulation of the Warta, cutting down the wicker thickets and strengthening the river banks with a concrete band, tightening the built development surrounding the forest (growth of the city), planned reconstruction of the valley landscape, development of riverbank areas, pollution and salinity of water in particular, as well as progressive soil depletion. Szafran (1959) also drew attention to the fact that the opposite banks of the Warta river were unprotected by greenery, with housing development and factories in Starołęka and Rataje. The author also remarked that the landscape of Dębina was distorted due to the elimination of aquatic undergrowth including willows, buckthorn, alder buckthorn and blackberries. The change in the landscape also took place as a result of the construction of a flood embankment, the development of filtration devices for municipal water supply systems, and the creation of garden plots (whereby the belt vegetation system was modified).

Currently, deciduous species of native origin dominate in the wooded area of Dębina. The picturesque quality of the trees is emphasized by grassy glades and four large ponds: Słoneczny, Dębowy, Borusa and Grundela, constituting the remains of the former Warta riverbed. The Warta river is an unquestionable landscape asset (although it is visible only from riverbank areas and from the bridges). Its waters form the foreground for the greenery and the urban development along the banks. The perception of vistas that feature Warta river, however, is small and limited to areas that are more easily accessible (see: Fig. 5). 


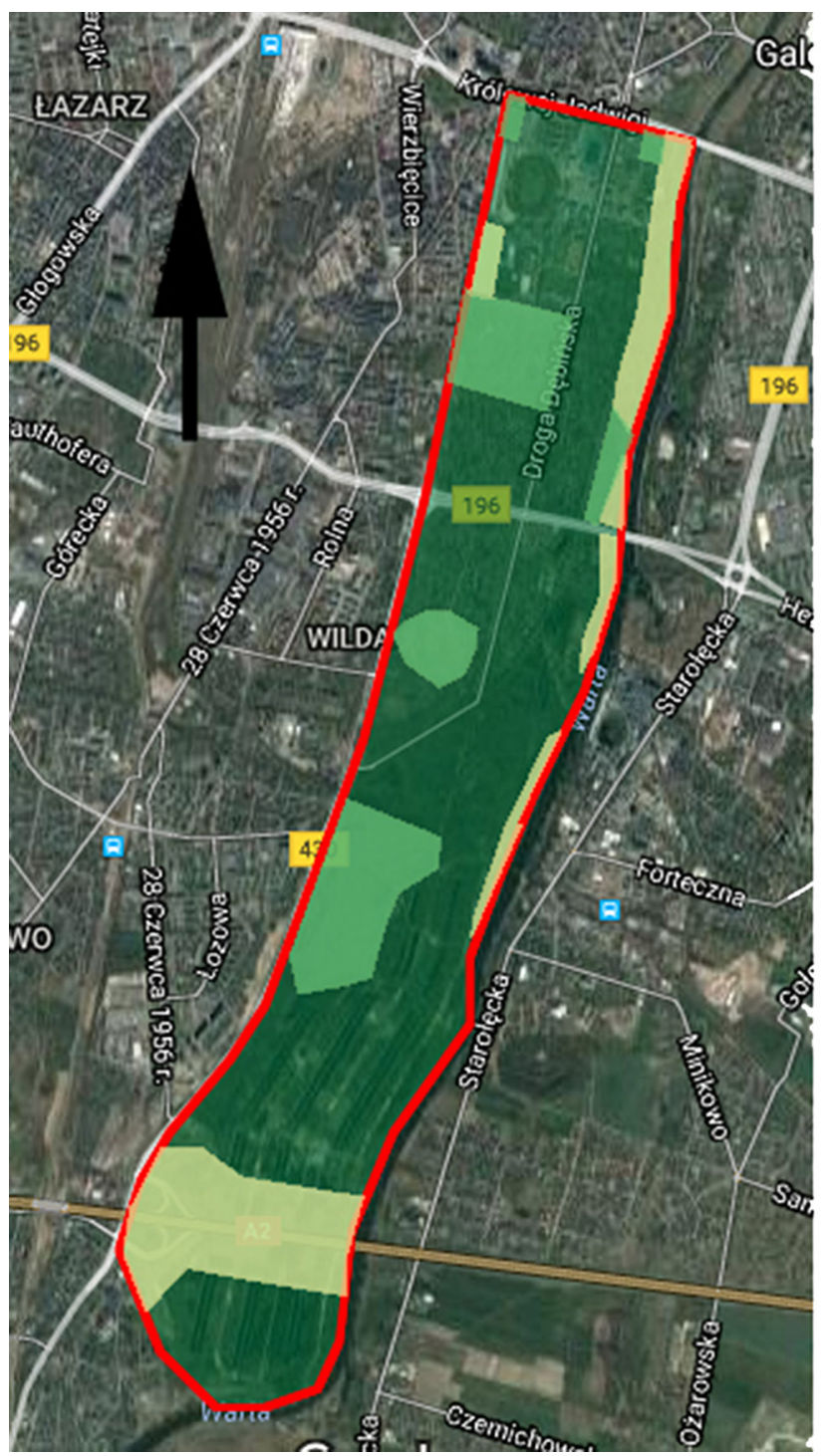

Most visual exposed areas

Medium visual exposed areas

Low visual exposed areas

Fig. 5. Diversification of areas in terms of visibility (Source: compiled by B. Łukasik)

From the highway bridge, apart from the river, the drinking water intake is visible along with rectangular infiltration ponds. Their regular outlines contrast against the naturally shaped greenery. From other sides, the area of the intake is virtually invisible, as are the complexes of family garden allotments (ROD) located in the northern part of the studied area. Currently, a significant share of high greenery and forests shelters large areas of Dębiec from the view. The A2 motorway is a very aggressive element in the local landscape. As a line investment project, along with the accompanying infrastructure elements, it disturbs the natural character of the area.

\section{Spatial changes}

Back in the first half of the nineteenth century, the area of today's Dębina was occupied primarily by cultivated areas and forests. Meadows and pastures had the largest share (241.66 ha, that is $40 \%$ of the analysed area). There were numerous watercourses 
and small water reservoirs, partly Warta oxbow lakes ( $13.01 \mathrm{ha}$, that is $2 \%$ of the analysed area). Buildings in the form of dispersed settlements were concentrated along the Dębińska road, and there were also buildings associated with "Gaj Ludwiki" (Louise's Wood or Eichwald), located in the centre of the forest complex. Built-up areas occupied $1 \%$ of the studied area (3.8 ha).

At the beginning of the twentieth century, the largest area in Dębina was occupied by arable land (266.52 ha, $44 \%$ of the total area), which replaced meadows and forests. The share of built-up areas increased considerably ( 22.28 ha, $4 \%$ of the total area, increasing by nearly 18.5 ha compared to 1830 , that is, by $486.32 \%$ ) (see: Fig. 6-7, Table 1).

Analyses of topographical maps from the end of the twentieth century show Dębina as an area with high forest cover (219.39 ha, $36 \%$ of the area, an increase of over 99 ha, that is by $36 \%$ compared to 1919), devoid of cultivated areas that have replaced forms of land use related to the functioning of Dębina as the southern green wedge of the city (areas with sports infrastructure, park greenery, allotment gardens). Interestingly, the area of built-up plots decreased slightly compared to the previous time section (down by 2.65 ha, or $11.9 \%$ ), and the buildings became more
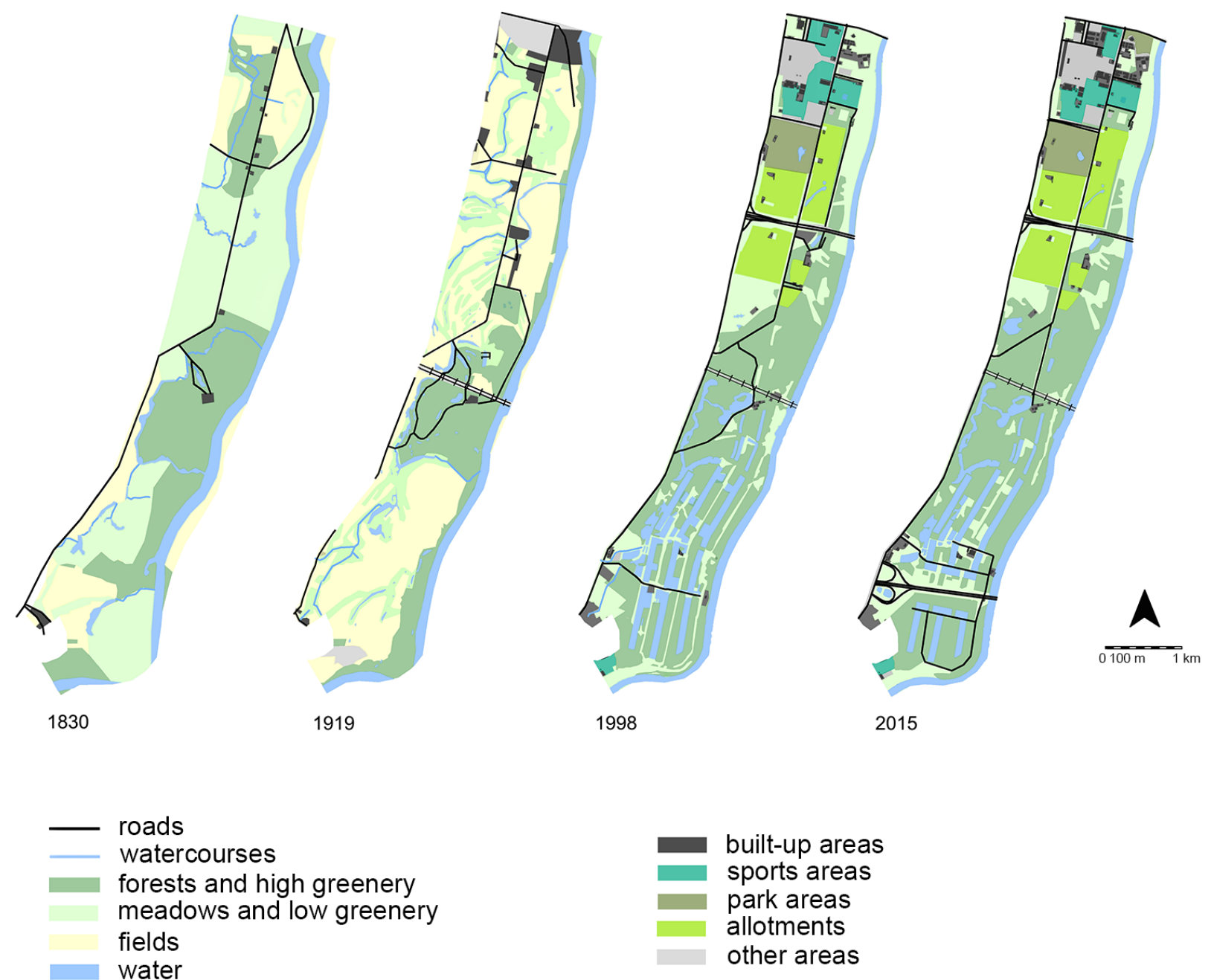

built-up areas sports areas park areas allotments other areas

Fig. 6. The development of Dębina in different periods (Source: compiled by A. Wilkaniec) 
dispersed. However, we should consider the fact that the buildings on the plots visible on the map from 1919 were not compact, and occupied a small area as opposed to large surface and cubic capacity of buildings constructed in the second half of the twentieth century. Also, the existing built-up areas in 1998 do not include individual development of allotment gardens and structures related to sports grounds (stadium, sports fields). The area of water reservoirs on Dębina increased (59.32 ha, i.e. 10\% share, which constitutes an increase of 38.7 ha, that is by $187.68 \%$ in relation to 1919). This was undoubtedly related to the accumulation of ponds in recreational areas and the construction of reservoirs for the needs of water intake (see: Fig. 6-7, Table 1).
Over the last 20 years, within Debina precinct, we saw an increase of areas occupied by high greenery and forests (an increase of nearly 10 ha, that is by $38 \%$ compared to 1998) and built-up areas (by more than 2 ha, that is $11.1 \%$ of the area in relation to 1998) at the expense of low green areas. On the other hand, the surface of water reservoirs decreased (a decrease of 8.8 hectares compared to 1998 , that is a $14.82 \%$ reduction), mainly due to the designation of a part of the water intake area for the construction of the A2 motorway. In the last two time sections, the share of the areas occupied by communication has significantly increased. The area of approximately 12.5 ha is occupied by the Edmund Szyc stadium located near the city centre, now long disused and falling into disrepair.

Table 1. Changes in the land cover and land use in Dębina, in consecutive periods in history (Source: compiled by A. Wilkaniec)

\begin{tabular}{|c|c|c|c|c|c|c|c|c|c|c|c|c|}
\hline \multirow[b]{2}{*}{$\begin{array}{l}\text { TYPE OF LAND } \\
\text { COVER/USE }\end{array}$} & \multicolumn{3}{|c|}{1830} & \multicolumn{3}{|c|}{$1919^{*}$} & \multicolumn{3}{|c|}{$1998 * *$} & \multicolumn{3}{|c|}{$2015 * * *$} \\
\hline & $\begin{array}{l}\underset{\mathbb{Z}}{\mathbb{J}} \\
\underset{\mathbb{Z}}{Z}\end{array}$ & 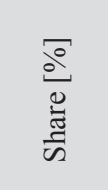 & 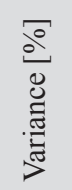 & 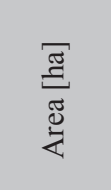 & 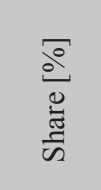 & 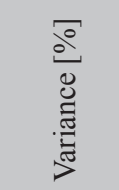 & 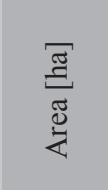 & 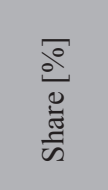 & 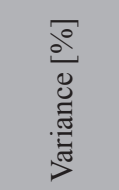 & 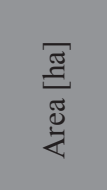 & 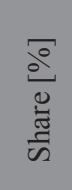 & 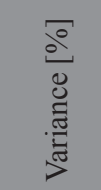 \\
\hline forests and high greenery & 181.27 & 30 & 100 & 120.36 & 20 & -33.6 & 219.39 & 36 & +82.28 & 228.92 & 38 & +4.34 \\
\hline $\begin{array}{l}\text { meadows and low } \\
\text { greenery }\end{array}$ & 241.66 & 40 & 100 & 99.89 & 17 & -58.67 & 125.21 & 21 & +25.35 & 115.9 & 19 & -7.44 \\
\hline fields & 105.71 & 17 & 100 & 266.52 & 44 & +152.12 & 0 & 0 & -100 & 0 & 0 & - \\
\hline Warta river & 58.8 & 10 & 100 & 50.8 & 8 & -13.61 & 40.11 & 7 & -21.04 & 41.27 & 7 & +2.9 \\
\hline other open water bodies & 13.01 & 2 & 100 & 20.62 & 3 & +58.49 & 59.32 & 10 & +187.68 & 50.53 & 8 & -14.82 \\
\hline built-up areas & 3.8 & 1 & 100 & 22.28 & 4 & +486.32 & 19.63 & 3 & -11.9 & 21.81 & 4 & +11.1 \\
\hline $\begin{array}{l}\text { sports areas and sports } \\
\text { infrastructure }\end{array}$ & 0 & 0 & - & 0 & 0 & - & 26.15 & 4 & 100 & 19.95 & 3 & -23.7 \\
\hline park areas & 0 & 0 & - & 0 & 0 & - & 18.24 & 3 & 100 & 21.39 & 4 & +17.27 \\
\hline allotment gardens & 0 & 0 & - & 0 & 0 & - & 58.43 & 10 & 100 & 59.29 & 10 & +1.47 \\
\hline other areas & 0 & 0 & - & 23.78 & 4 & 100 & 37.77 & 6 & +58.83 & 45.19 & 7 & +19.65 \\
\hline TOTAL & 604.25 & 100.00 & - & 604.25 & 100.00 & - & 604.25 & 100.00 & - & 604.25 & 100 & - \\
\hline
\end{tabular}

*baseline data from 1830,**baseline data from 1919, *** baseline data from 1998 
1830

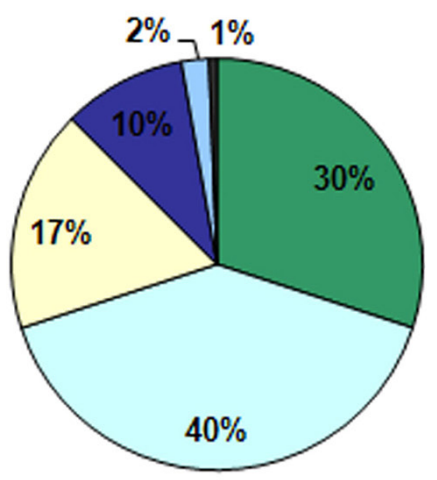

1998

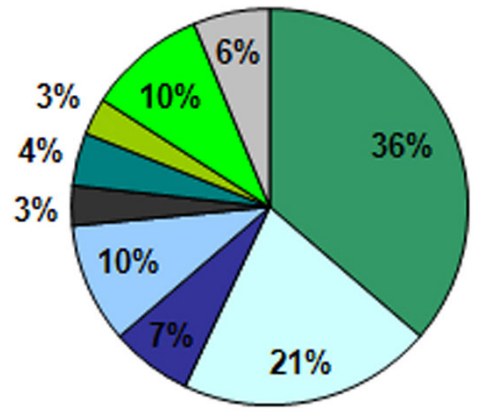

1919

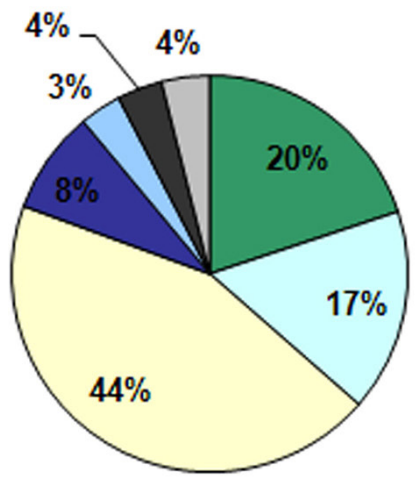

2015

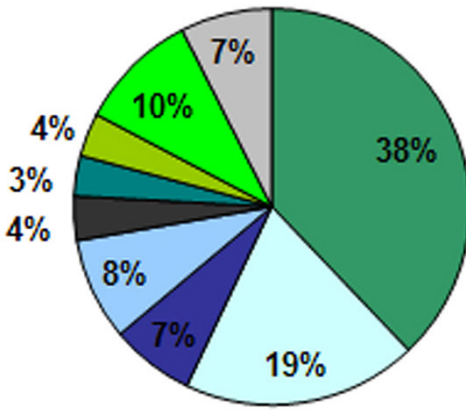

$\square$ forests and high greenery

$\square$ meadows and low greenery

$\square$ fields

$\square$ Warta river

$\square$ other open water

$\square$ built-up areas

$\square$ sport areas

$\square$ park areas

$\square$ allotments

$\square$ other areas

Fig. 7. The percentage share of areas with different types of development (Source: compiled by A. Wilkaniec)

\section{CONCLUSIONS}

The research we have conducted proves that the largest transformations in the Dębina region occurred as a result of intentional human activity or as an unintentional side effect of various forms of human activity. Numerous changes constituted a serious interference in the local landscape, and contributed to the loss of valuable natural assets.

Significant transformations of natural assets and landscape qualities of the Dębina region occurred, among others, due to:

- Forest management. Afforestation often took place without respect for the native dendroflora, cuts and thinning were carried out, fallen trees were removed.
- Transforming the forest into a park, which was associated with the necessity of introducing facilities for tourists (building a cafe, introducing new roads, cutting trees to open the vistas towards the city).

- Development of communication infrastructure (construction of a railway line in 1874, and a bridge in 1875, Luisenhain station in 1877, construction of a new road through Dębiec, construction of the A2 motorway in 2003). The necessary, but highly pronounced line infrastructure elements have been introduced into the landscape. On the other hand, the course of the motorway contributed to the opening of vistas of the Warta river and the area of the water intake with ponds, which had not been visible to Dębina's visitors before that. 
- The placement of the water intake caused a deterioration of water conditions and resulted in substantial losses in the forest stand. Habitats were transformed, and their species composition has changed. Currently, the Dębiński forest and other areas close to the water intake constitute an area of indirect protection (a buffer zone), which gives them legal protection and limits the possibility of further development of these areas.

The tendency to expand the forest area and high greenery at the expense of open areas, which is manifestly clear in the analyses of land coverage and land use, limits the landscape visibility of many fragments of Dębina. On the other hand, large areas intended only for a small group of users (such as the allotment gardens) or completely enclosed (such as the water intake area) reduce the recreational role of the area and the availability of its picturesque qualities. Above all, the visibility of the river is limited, as there is no access thereto on a long stretch of the bank.

The results of the analyses lead us to the conclusion that, despite the existing transformations, Dębina is still primarily a valuable reserve of natural assets. Not only biodiversity is important, but also the extent of naturally maintained areas, supporting the sustainability of ecosystems. In order to preserve the existing assets, it is necessary to strive to maintain the existing use, as extensive as possible. Studies have shown that the landscape qualities of Dębina are limited, but this does not prevent the pursuit of the recreational function by the city residents. In the context of actions taken today by the leaders of many European cities, aimed at shaping coherent systems of green areas with the view to providing the most favourable living conditions for the residents, preservation of Dębina as an integral component of the southern green wedge of Poznań's system of green spaces should remain a priority when making any planning decisions.

To sum up, Dębina area is subject to typical natural and landscape transformations related to anthropogenic pressure. The changes characteristic of the urbanization process are visible within this area - such as fragmentation of the area caused by the development of communication; loss of agricultural land in favour of meadow areas constituting a reserve for construction purposes; changing character of borders between particular fragments from blurred to rectilinear; exclu- sion of access to large fragments of areas, etc. For the stability of ecosystems in the area of Poznań's Dębina, it is important to counteract further fragmentation of this area and any construction development therein. It is advisable to maintain allotment gardens, park and forest greenery, meadows, low greenery and waters as well as the zone of the water intake.

\section{REFERENCES}

Border, J. A., Newson, S. E., White, D. C., Gillings, S. (2017). Predicting the likely impact of urbanisation on bat populations using citizen science data, a case study for Norfolk, UK. Landscape and Urban Planning, 162, 44-55.

Bradshaw, C. J. (2012). Little left to lose: deforestation and forest degradation in Australia since European colonization. Journal of Plant Ecology, 5(1), 109-120.

Bruschi, D., Garcia, D. A., Gugliermetti, F., Cumo, F. (2015). Characterizing the fragmentation level of Italian's National Parks due to transportation infrastructures. Transportation Research Part D: Transport and Environment, 36, 18-28.

Celka, D. (2002). Królestwo grzybów In:: Wśród zwierząt i roślin. Kronika Miasta Poznania. 3, 70-80.

Chmielewski, J. M. (2001). Teoria urbanistyki w projektowaniu i planowaniu miast. Oficyna Wydawnicza Politechniki Warszawskiej, Warszawa Chmielewski, T. J. (2012). Systemy krajobrazowe. Struktura-funkcjonowanie-planowanie. Warszawa: PWN

Dyderski, M., Wrońska-Pilarek, D. (2015). Szata roślinna nowo powstałych użytków ekologicznych „Dębina I” oraz „Dębina II” w Poznaniu. Nauka Przyr. Technol., 9, 4, \#46. DOI: 10.17306/J.NPT.2015.4.46

Fu, W., Liu, S., Dong, S. (2010). Landscape pattern changes under the disturbance of road networks. Procedia Environmental Sciences, 2, 859-867.

Górski, J. (2013). Uproszczony plan urządzenia lasu dla lasów własności Miasta Poznań w użytkowaniu wieczystym Aquanet S.A. w Poznaniu na okres od 01.01.2013r. do 31.12.2022r.

Hamer, A. J., McDonnell, M. J. (2008). Amphibian ecology and conservation in the urbanising world: a review. Biological conservation, 141(10), 2432-2449.

Hanisch, F. (1909). Welche Bedeutung haben Stadtwaldanlagen für Industrie - und Grossstadte? Die Gartenkunst. 11, 11, 190-191.

Hoffmann, A. (1904). Hygienishe und soziale Betätigung Deutscher Städte auf den Gebieten Gartenbaus. Druck von August Bagel. Düsselldorf. 322-324. 
Kaniecki, A. (2004). Zmiany sieci wodnej w dolinie Warty w południowej części Poznania. W: Dębiec. Kronika Miasta Poznania. Poznań: Wydawnictwo Miejskie. 1, $27-41$.

Karolczak, W. (1993). Parki publiczne, skwery i promenady dawnego Poznania (do 1914 r.) w: Zieleń i architektura. Kronika Miasta Poznania. 3-4, 38-97.

Karolczak, W. (2004). Gaj Ludwiki, czyli rekreacja w Lasku Dębińskim. In: Dębiec. Kronika Miasta Poznania. N.1. $182-210$

Kepel, A. (2001). Porosty. In: D. Wrońska-Pilarek, W. Danielewicz, S. Gałązka, R. Gornowicz, T. Mizera, G. Maciorowski Badania florystyczno-faunistyczne oraz ocena naukowa walorów przyrodniczych użytku ekologicznego „Dębina”. Maszynopis. WOŚ Poznań.

Kiehl, W. (1908). Der Eichwald bei Posen. Gartenkunst. 10, 3, 43-45.

Kodym-Kozaczko, G. (2014). Warta w planach zagospodarowania przestrzennego miasta Poznania. In: Warta. Kronika Miasta Poznania. 1, 205-228.

Kodym-Kozaczko G., Kozaczko M. (2014) Plan ogólny zabudowy Poznania (1931-1939) na tle europejskiej teorii i praktyki budowy miast. In: Architektura lat międzywojennych i jej ochrona w cyklu Modernizm w Europie - modernizm w Gdyni. http://gdynia.pl/ zabytki/cykl-modernizm-w-europie-modernizm-wgdyni,7219/architektura-lat-miedzywojennychi-jej -ochrona-wersja-elektorniczna,425028 opublikowano 08.04 .2014

Liszkowska, E., Ratyńska, H., Przybyłek, P. (2009). Raport o oddziaływaniu na środowisko projektowanej przebudowy ujęcia wody „Poznań-Dębina” w Poznaniu. Materiały niepublikowane udostępnione przez Aquanet S.A.

Macias, A., Bródka, S. (2014). Przyrodnicze podstawy gospodarowania przestrzenią. Warszawa: PWN.

Madaj, A. (2004). Dębiecki odcinek autostrady A2. In: Dębiec. Kronika Miasta Poznania. N. 1. S. 397-406

Maheshwari, B., Bristow, K. L. (2016). Peri-urban water, agriculture and urbanisation. Agricultural Water Management, 176, 263-265.

Mapa strefy ochronnej ujęcia wody „Dębina” w Poznaniu - załącznik nr 1 do Rozporządzenia Dyrektora Regionalnego Zarządu Gospodarki Wodnej w Poznaniu z dnia 30 października $2015 \mathrm{r}$.

Mapa topograficzna w skali 1:10 000, opracowanie $1998 \mathrm{r}$., sekcje: n-33-130-d-d-1, n-33-130-d-d-2, n-33-130-d -d-3, Główny Urząd Geodezji i Kartografii

Messtischblatt - niemiecka mapa stolikowa założona w latach 1888 r., wydana w 1919 r., w skali 1: 25000; Posen
Süd, sekcja 3667, http://mapy.amzp.pl/maps.shtml (dostęp w lutym 2016)

Nowacki, J. (1964). Archidiecezja poznańska w granicach historycznych i jej ustrój. T. 2. Poznań: Księgarnia św. Wojciecha. 767-768

Ortofotomapa dostępna online w bibliotekach programu ArcGIS z roku 2015

Orzeczenie Prezydium WRN w Poznaniu z dn.15.12.1956 r. O uznaniu za pomnik przyrody (Dz. Urz. z 1957 r. Nr 3, poz. 10)

Paradowska, M. (2004). Bambrzy w Dębcu. In: Dębiec. Kronika Miasta Poznania. N.1. Poznań: Wydawnictwo Miejskie 61-78

Pogorzelski, Z. (1973). Terytorialny rozwój Poznania w latach 1900-1975, Kronika Miasta Poznania. 1, 62-64.

Przybyłek, J. (2004). Ujęcie wody Dębina. In: Dębiec. Kronika Miasta Poznania. 1, 379-396

Richling, A., Solon, J. (2011). Ekologia krajobrazu. Warszawa:PWN.

Ritschl, G. (1850). Flora des Grossherzogthums Posen, im Auftrafe des naturhistorischen Vereins zu Posen, Berlin, Druck und Verlag von E. S. Mittler und Sohn

Rozporządzenie Rady Ministrów Rzeczypospolitej Polskiej z dnia 17 grudnia 1924 r. Dziennik Ustaw RP nr 112 z 24 grudnia 1924 roku, poz. 996

Schumann, E. (1904). Der Eichwald bei Posen. Eine koleopterologische Betrachtung. Zeitschrift der Naturwissenschaftlichen Abteilung. Deutsche Gesellschaft für Kunst und Wisssenschaft in Posen. 11, 1, 15-21.

Szafran, H. (1959). Miasto Poznań i okolica. Poznań: Poznańskie Towarzystwo Przyjaciół Nauk. 82-95

Szponar, A. (2003). Fizjografia urbanistyczna. Warszawa: PWN.

Szulczewska, B. (2004). Planowanie przestrzenne jako instrument realizacji sieci ekologicznych: miedzy teorią a praktyką. In: A. Cieszewska (ed.) Płaty i korytarze jako elementy struktury krajobrazu - możliwości i ograniczenia koncepcji, Problemy Ekologii Krajobra$\mathrm{zu}, \mathrm{XIV}$.

Treby, D. L., Castley, J. G. (2016). The impacts of historical land-use and landscape variables on hollow-bearing trees along an urbanisation gradient. Urban forestry \& Urban Greening, 15, 190-199.

Uchwała nr CV/610/94 Rady Miejskiej Poznania z dnia 10 maja 1994 r. w sprawie utworzenia użytków ekologicznych i zespołów przyrodniczo-krajobrazowych wraz z załącznikami.

Uchwała Rady Miasta Poznania z dnia 10 grudnia 2013 r. nr LX/924/VI/2013 i LX/925/VI/2013 
Urmesstischblatt - niemiecka mapa stolikowa z 1830 r., w skali 1:25000, sekcja 1997, zbiory Staatsbibliothek zu Berlin - Preußischer Kulturbesitz

Urbańska, M., Gierszal, H., Andrzejewski, W. (2015). Krótka historia turystycznej promocji użytków ekologicznych Poznania. Studia i materiały CEPL w Rogowie, 17, 45/4. 266-272.

Ustawa z dnia 7 grudnia 2000 r. o zmianie ustawy o ochronie przyrody (Dz. U. z 2001 r. Nr 3, poz. 21)

Wodziczko, A. (1930a). Ginąca Dębina w Poznaniu. Ochrona Przyrody. 10.

Wodziczko, A. (1930b). Zieleń miast z punktu widzenia ochrony przyrody. In: Ochrona przyrody Państwowa Rada Ochrony Przyrody. R. 10, 43.

Wodziczko, A. (1936). Rola lasów w życiu miasta. In: Więcej lasów Poznaniowi! Redakcja Kuriera Poznańskiego. Poznań: Nakładem Towarzystwa Miłośników Miasta Poznania
Wrońska-Pilarek D., Danielewicz W., Gałązka S., Gornowicz R., Mizera T., Maciorowski G. (2001). Badania florystyczno-faunistyczne oraz ocena naukowa walorów przyrodniczych użytku ekologicznego „Dębina”. Maszynopis. WOŚ Poznań.

Zaremba, P. (1946). Planowanie zieleni i krajobrazu. Warszawa: Instytut Wydawniczy Budownictwa.

Zawada, D. (2015). Liczebność, preferencje siedliskowe i przebieg aktywności dobowej Aeshna affinis na terenie ujęcia wody Dębina w Poznaniu. Praca magisterska zrealizowana na Wydziale Biologii Uniwersytetu im. Adama Mickiewicza w Poznaniu pod kierunkiem dr hab. Rafała Bernarda.

Zhang, X. Q. (2016). The trends, promises and challenges of urbanisation in the world. Habitat International, 54, 24-252.

\section{DOLINA WARTY W REJONIE POZNAŃSKIEJ DĘBINY - ZMIANY W POKRYCIU I UŻYTKOWANIU TERENU W KONTEKŚCIE WALORÓW PRZYRODNICZYCH I KRAJOBRAZOWYCH}

\section{ABSTRACT}

\section{Cel pracy}

Położona na południe od centrum Poznania Dębina to cenny obszar przyrodniczo-krajobrazowy, wykorzystywany na cele rekreacyjne. Celem pracy jest identyfikacja walorów przyrodniczo-krajobrazowych i ustalenie przyczyn ich przekształceń na obszarze Dębiny oraz określenie poziomu zmian w użytkowaniu i pokryciu terenu, aby uchwycić zależności między uwarunkowaniami przyrodniczo-krajobrazowymi a działalnością człowieka.

\section{Materiał i metody}

W toku prac przeprowadzona zostanie analiza funkcjonalna i identyfikacja współczesnych zagrożeń dla Dębiny. Badania wykonane zostaną przy użyciu narzędzi GIS, w oparciu o materiały historyczne i współczesne opracowania kartograficzne.

\section{Wyniki i wnioski}

Istotne przekształcenia środowiska w tym rejonie zapoczątkowała u progu XX w. budowa ujęcia wody. Duży wpływ miały również inne inwestycje związane z rozwojem miasta i regionu. Zaistniałe niekorzystne dla przyrody i krajobrazu przeobrażenia stały się powodem podjęcia działań naprawczych, zmierzających do zachowania i ochrony komponentów naturalnych. Dziś Dębina jest przykładem współistnienia i wzajemnych powiązań elementów przyrodniczych i kulturowych. Jako obszar położony w dolinie rzeki Warty, stanowi element korytarza ekologicznego o randze krajowej i wpisuje się jednocześnie w europejską sieć ekologiczną ECONET PL.

Wyniki badań w postaci określenia skali zmian w pokryciu i użytkowaniu terenu w kolejnych przekrojach czasowych mogą być podstawą do sformułowania wytycznych dotyczących dalszego gospodarowania na tym terenie i ochrony posiadanych przez niego walorów przyrodniczych.

Słowa kluczowe: urbanizacja doliny rzecznej, degradacja ekosystemów, sieć ekologiczna, zagrożenia krajobrazowe 